\title{
The presence of whale sharks based on oceanographic variations in Cenderawasih Bay National Park, Papua, Indonesia
}

\author{
JAFRY FERDINAN MANUHUTU ${ }^{1,2, \boldsymbol{v}}$, DEWA GEDE RAKA WIADNYA ${ }^{3}$, ABU BAKAR SAMBAH ${ }^{3}$, \\ ENDANG YULI HERAWATI ${ }^{4}$ \\ ${ }^{1}$ Graduate Program, Faculty of Fisheries and Marine Science, Universitas Brawijaya. Jl. Veteran, Malang 65145, East Java, Indonesia. \\ Tel.: +62-341-553512, Fax.: +62-341-557837, ^email: jfmanuhutu@ student.ub.ac.id; jfmanuhutu73@gmail.com \\ ${ }^{2}$ Faculty of Fisheries and Marine Science, Universitas Papua. Jl. Amban Salju, Monokwari 98314, West Papua, Indonesia \\ ${ }^{3}$ Department of Fisheries, Faculty of Fisheries and Marine Science, Universitas Brawijaya. J1. Veteran, Malang 65145, East Java, Indonesia \\ ${ }^{4}$ Department of Aquatic Resources Management, Faculty of Fisheries and Marine Science, Universitas Brawijaya. Jl. Veteran, Malang 65145, East Java, \\ Indonesia
}

Manuscript received: 21 September 2021. Revision accepted: 22 October 2021.

\begin{abstract}
Manuhutu JF, Wiadnya DGR, Sambah AB, Herawati EY. 2021. The presence of whale sharks based on oceanographic variations in Cenderawasih Bay National Park, Papua, Indonesia. Biodiversitas 22: 4948-4955. Oceanographic factors have an important role in the study of estimating the distribution of fish resource habitats. Sea Surface Temperature (SST), Sea Surface Chlorophyll (SSC), Current Speed, Sea Surface Height (SSH), and bathymetry are important parameters that have been used in estimating the habitat of certain species. Through analyzing these environmental factors, research on the appearance and distribution of whale shark habitats in the Cenderawasih Bay National Park in Papua, Indonesia, utilized field observation data and satellite imagery. This study applied data on the presence of whale sharks and oceanographic parameter data from satellite recordings during $2019-2020$. Analysis of the relationship and habitat modeling between the monthly presence of whale sharks and environmental parameters was carried out through the Generalized Additive Model (GAM) statistical approach and spatial analysis through the Geographic Information System approach. In the GAM analysis, data on the presence of whale sharks was used as a response variable. In contrast, the predictor variables consisted of SST, SSC, current speed, SSH, and bathymetric data. The results showed that the highest frequency of whale shark presence occurred in the transitional monsoon, with an average presence of $31.77 \pm 4.00 \%$. The study also showed that all predictors showed a highly significant relationship $(\mathrm{P}<0.001)$ to the number of whale sharks present. SST values range from $30.3-$ $31.3^{\circ} \mathrm{C}$, SSC of $0.39-0.86 \mathrm{mg} / \mathrm{L}$, the current speed of $0.46-0.65 \mathrm{~m} / \mathrm{s}, \mathrm{SSH}$ showed 0.63 to $1.00 \mathrm{~cm}$, and bathymetry between $40-50$ $\mathrm{m}$. In the GAM model, the SST and SSC parameters were the two most important parameters that affect the presence of whale sharks, followed by SSHD, depth (bathymetry), and current parameters.
\end{abstract}

Keywords: Chlorophyll- $a$, monsoon, season, sea surface temperature

\section{INTRODUCTION}

The whale shark (Rhincodon typus, Smith 1828) is an endangered species of filter-feeding shark and has a worldwide distribution area in both tropical and warm seas (Pierce and Norman 2016). A greater presence of individuals is found in high seas waters (Clingham et al. 2016; Ryan et al. 2017; Petatán-Ramírez et al. 2020). In contrast, immature males dominate coastal areas and congregate seasonally (Donati et al. 2016; Pajuelo et al. 2018). Based on the research, to date, there are 25 locations of whale shark occurrences identified in the world (Andrzejaczek et al. 2016; Norman et al. 2017; Copping et al. 2018). However, several locations of whale shark presence were recorded throughout the year (Norman et al. 2017), often appearing on the coast seasonally. Some individuals showed higher site fidelity (Araujo et al. 2017; Norman et al. 2017; Diamant et al. 2018). The appearance of the whale shark is well documented and coincides with high marine productivity (Rohner et al. 2018) in areas characterized by certain oceanographic conditions such as upwelling, fronts, and seafloor features (e.g., seamount and continental slope). This environmental phenomenon has increased food availability (Hacohen-Domené et al. 2015; Ryan et al. 2017; Copping et al. 2018).

In general, the distribution and abundance of the whale shark are influenced by several oceanographic processes such as upwelling, coastal currents, and fronts, which increase the productivity of the surrounding environment (Taylor 1996; Eckert and Stewart 2001; Duffy 2002; Norman 2002; Ryan et al. 2017). In places where whale sharks appear around the world, it is often associated with warm water temperatures and other environmental parameters that can increase the productivity of the marine environment, which supports the creation of localized concentrations of food. Several studies on how environmental conditions affect the presence of Whale Sharks. For example, Robinson et al. (2017) reported that the number of whale sharks in pelagic surface waters in the western Indian Ocean was shown to be correlated with sea surface temperature (SST). Likewise, the study by Rowat et al. (2009) reported that coastal waters, sea surface temperature, wind speed, chlorophyll- $a(\mathrm{Chl}-a)$, and bathymetry were significant predictors and correlated with whale shark numbers in aerial surveys in Seychelles. 
Further, large-scale factors influencing oceanographic processes, such as the Southern Oscillation Index and wind shear at Ningaloo Reef, or monsoon winds in the Maldives have been linked to shifts in abundance and distribution of planktivorous elasmobranchs (Wilson et al. 2001; Sleeman et al. 2010; Anderson et al. 2011).

Environmental factors play a role in explaining whale shark observation trends (Sequeira et al. 2014). Identifying and understanding areas used during significant periods of their life is critical for future conservation efforts (Hays et al. 2016). Biophysical environmental data close to time series (in Time Series) around the world can be obtained from satellite remote sensing. In recent decades, satellite remote sensing has become an ecological instrument for environmental monitoring (Chassot et al. 2011) and manages sustainable fisheries levels (Klemas et al. 2013). Biological and ecological data in Cenderawasih Bay National Park is needed to understand the preferred and used habitats in the sustainable management of Whale Shark. Several bioecological studies on the presence of whale sharks have been carried out in recent years, but to date, there has been very little research on oceanographic variations associated with the presence of whale sharks. Thus, the purpose of this study is to analyze variations in oceanographic parameters and their relationship to the seasonal presence of whale sharks using the Generalized Additive Model (GAM) in the Cenderawasih Bay National Park area, Papua, Indonesia.

\section{MATERIALS AND METHODS}

\section{Research location}

The research was conducted in the waters of Cenderwasih Bay National Park, Papua, Indonesia. This area is a part of Cenderawasih Bay. Cenderwasih Bay National Park is located between two provinces, namely West Papua and Papua Provinces. Geographically, the research location is located at $134^{\circ} 52^{\prime} 15.23^{\prime \prime}-135^{\circ} 4^{\prime} 4.5^{\prime \prime} \mathrm{E}$, and $3^{\circ} 12^{\prime} 15.39^{\prime \prime}-3^{\circ} 22^{\prime} 11.18^{\prime \prime} \mathrm{S}$ (Figure 1).

\section{Dataset}

This study utilizes satellite imagery data in providing water environmental parameters Sea Surface Temperature (SST), chlorophyll- $a$ (Chl-a), current and depth. Data processing was carried out with the help of SeaWiFS Data Analysis System (SeaDAS) 7.3.2 software in the extraction process oceanographic parameter values from satellite data, $\mathrm{R}$ studio software for GAM modeling and statistical analysis, and Geographic Information System software for the mapping process.

\section{Whale shark presence data}

Data on the appearance of whale sharks was carried out by making direct observations in the field of individual whale sharks encountered. In addition, participatory mapping activities involving fishers were also carried out through recording lookbooks by Bagan fishermen around the research location. The data obtained in the form of the number of whale shark presence, the time of appearance, and the position of the arrival of the whale shark include latitude information by using GPS.

\section{Oceanographic Data}

Sea Surface Temperature Parameters (SST) and chlorophyll- $a$ (Chl- $a$ ) data were downloaded from the Aqua/ MODIS satellite imagery in SMI format from the Ocean Color official website (http://oceancolor,gsfc,nasa,gov). The downloaded data was in the form of geometrically corrected level 3 monthly data with a resolution of $4 \mathrm{~km}$ in May 2019-april 2020. The Aqua MODIS SST and daily chlorophyll- $a$ image data were composited monthly or called monthly data merging using SeaDAS 7.2 software. The aim is to see the phenomenon of temporal variability of chlorophyll-a SST at the study site. The monthly composite is the daily average of each month for one year. In addition, depth data (Bathymetry) was obtained from GEBCO (The General Bathymetric Chart of the Oceans), which was downloaded from the website of the British Oceanographic Data Centre (www.bodc.ac.uk), the depth data obtained had a resolution of 30 arc-seconds or less than 1 Kilometer (GEBCO 2003). Types of oceanographic and environmental parameters based on spatial resolution are shown in Table 1.

\section{Data analysis}

Generalized Additive Model (GAM) is an alternative statistical model if a linear relationship between two variables is not found (Guisan et al. 2005; Elith and Leathwick 2009). In general, GAM uses a smoothing curve to model the relationship between the presence of whale sharks (response variable) and oceanographic variables, which are called predictor variables (Alfonso et al. 2014). Therefore, in general, it can be said that the Generalized Additive Model (GAM) is used to determine the nature of the relationship between the presence of whale sharks and environmental variables. The GAM model was created using R software version 3.5.3 using the GAM function from the mgcv package (Wood 2006), with the number of whale sharks as the response variable and SST, chlorophyll- $a$, current, bathymetry, and SSHD as predictor variables. Then, Generalized Additive Model (GAM) in the form of Equation (1) is applied. Predictors are considered significant to explain the effect of oceanography. If the deviation (residual) and Akaike Information Criteria (AIC) decreases with each addition of the variable and the final probability of the variable is lower than $0.01(\mathrm{P}<0.01)$ (Guisan and Thuiller 2005; Elith and Leathwick 2009). 

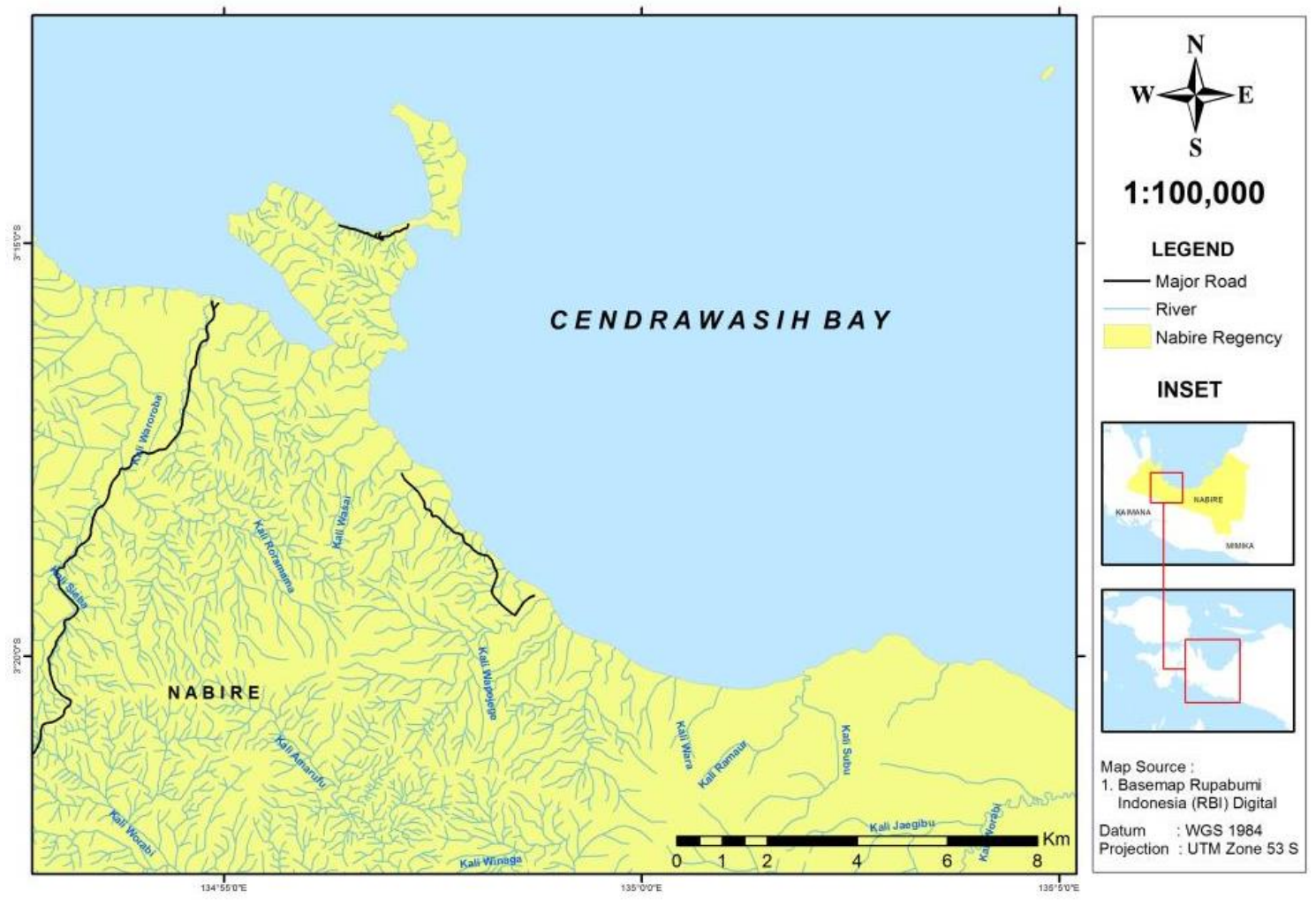

Figure 1. Research location of Cenderwasih Bay National Park, Papua, Indonesia

Table 1. Types of oceanographic and environmental parameters based on spatial resolution.

\begin{tabular}{|c|c|c|c|}
\hline Biophysical variables & Data source & Temporal coverage & $\begin{array}{c}\text { Spatial } \\
\text { resolution }(\mathbf{k m})\end{array}$ \\
\hline Sea Surface Temperature (SST) & MODIS Level 3 & Monthly composition & 4 \\
\hline Chlorophyll- $a$ & MODIS level 3 & Monthly composition & 4 \\
\hline Current & AVISO & Monthly seasonal & \\
\hline Sea Surface Height Distribution (SSHD) & AVISO & Monthly composition & \\
\hline Depth & The General Bathymetric Chart of the Oceans & Monthly composition & 0.250 \\
\hline
\end{tabular}

Smoothing curve (Figure 6), the $\mathrm{x}$-axis shows the value of the explanatory variable and the $y$-axis indicates a smoother contribution to the corresponding value or a more significant role. The horizontal line represents the observed data point value. The dotted line shows the $95 \%$ confidence interval for each estimator variable. The horizontal line at zero indicates no influence of the parameter. The percentage value is higher if the Generalized Additive Model (GAM) function developed is above the zero axis, which means a strong (positive) influence of a parameter and if below the zero axis indicates a weak (negative) impact of a parameter on the presence of whale sharks.

\section{RESULTS AND DISCUSSION}

\section{Whale shark presence frequency}

Based on the analysis of the frequency of the presence of whale sharks by season, the presence in the transitional monsoon I (March-May) was the highest in each season with an average of $31.77 \pm 4.00 \%$, followed by the transitional monsoon II with an average presence of 26.95 $\pm 2.14 \%$. Meanwhile, the west and east monsoons are the lowest averages, respectively $24.47 \pm 2.77 \%$ and $16.81 \pm$ $3.65 \%$. The frequency of the presence of whale sharks by season is shown in Figure 2.

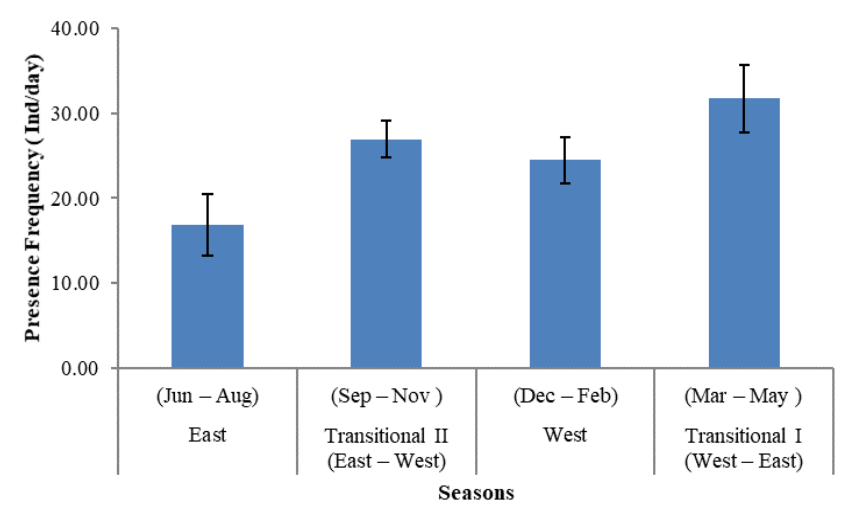

Figure 2. The presence frequency of the whale sharks in different seasons 
Whale shark aggregations usually occur seasonally in several locations around the world, this is very different at Cenderawasih Bay locations, where whale shark aggregations are always routine throughout the year (Stewart 2012). This shows that whale sharks at Cenderawasih Bay locations have site fidelity to the location (Cagua et al. 2015; Donati et al. 2016). Although some individual whale sharks at this location frequently travel out of Cenderawasih Bay. This is supported by Stewart (2012), who found that whale sharks frequently travel out and back into Cenderawasih Bay using satellite tagging. In this study, the highest frequency of whale shark presence occurred in the transitional monsoon. This is because, in the transitional monsoon, there is a transition process of water mass, increasing sea surface temperature. This event dramatically affects the high availability of chlorophyll- $a$ in the sea (Siswanto et al. 2020). The high abundance of phytoplankton (Chlorophyll-a) will attract the abundance of zooplankton and small fish (herbivorous). Prey availability is a consumer for pelagic fish, including whale sharks (Rohner et al. 2017).

\section{Temporal distribution of Sea Surface Temperature (SST) and Chlorophyll-a}

Based on the calculation of the distribution of Sea Surface Temperature (SST) and chlorophyll- $a$ temporally during the one-year study (time series), it can be seen in Figure 3 where the highest average Sea Surface Temperature (SST) was in November at $31.54{ }^{\circ} \mathrm{C}$ and the lowest in July of $30.17^{\circ} \mathrm{C}$. Meanwhile, the distribution of chlorophyll- $a$ shows the highest average in March of 0.71 $\mathrm{mg} / \mathrm{L}$ and the lowest in November of $0.27 \mathrm{mg} / \mathrm{L}$.

Based on the results of the Generalized Additive Model (GAM) analysis showed that the predictor of Sea Surface Temperature (SST) and Chlorophyll- $a$ were the most significant primary predictor model for shark abundance (Sequeira et al. 2012; Sequeira et al. 2014). This was indicated by the Akaike Information Criterion (AIC) value was the lowest and Cumulative Deviance Explained (CDE) was the highest (Table 2). In this study, the highest average Sea Surface Temperature was about $30.3-31.2{ }^{\circ} \mathrm{C}$ (Figure 6 ), where the range of average Sea Surface Temperature (SST) is almost the same as the results of research by Ihsan et al. (2018) with an average Sea Surface Temperature range between $30.5-31.3{ }^{\circ} \mathrm{C}$. This is very suitable for the presence of whale sharks. Several studies have shown that whale sharks are generally found in the Sea Surface Temperature range between $18-32{ }^{\circ} \mathrm{C}$ (Eckert and Stewart 2001; Rowat and Engelhardt 2007; Sleeman et al. 2007; Sequeira et al. 2012). Therefore, the relationship between whale shark abundance and predictors of Sea Surface Temperature has a clear correlation (Wilson et al. 2001; Sequeira et al. 2012; Hacohen-Domené et al. 2015). Meanwhile, the average chlorophyll- $a$ in this study was relatively high, ranging between $0.40-0.80 \mathrm{mg} / \mathrm{L}$, presumably due to the upwelling process. According to Siswanto et al. (2020), the high chlorophyll- $a$ in the northern Papua is due to the upwelling process. The concentration of chlorophyll- $a$ in this area attracts larger predators, including whale sharks (Sleeman et al. 2007;
McKinney et al. 2012; Rohner et al. 2013; CárdenasPalomo et al. 2018).

\section{Distribution of surface currents by season}

The analysis results of the spatial distribution of currents are highest in the east monsoon of $0.61 \mathrm{~m} / \mathrm{s}$ and the lowest in the transitional monsoon II (West-East) with a current speed of $0.41 \mathrm{~m} / \mathrm{s}$. (Figure 4 ).

\section{Sea Surface Height Distribution (SSHD) by season and bathymetric of the research site}

Observation results of Sea Surface Height Distribution (SSHD) by seasons show that the transitional monsoons I and II are the highest of $0.41 \pm 0.39$. In contrast, the West and East monsoons have the lowest value, wherein the East monsoon of $0.40 \pm 0.38$ and the West monsoon of $0.39 \pm$ 0.38 (Figure 5).

The results of a water bathymetric survey at the research site in the Kwatisore waters, Nabire Bay Cenderawasih National Park which is described as a whale shark habitat. Based on the depth analysis from the satellite, it can be seen that the research site has a depth ranging from 10 meters to a depth of 60 meters (Figure 6).

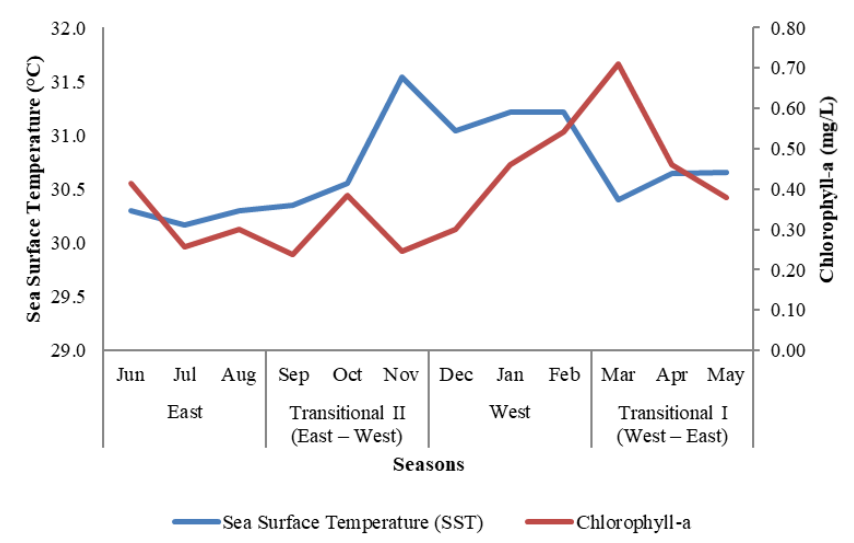

Figure 3. Temporal distribution of sea surface temperature (SST) and chlorophyll- $a$

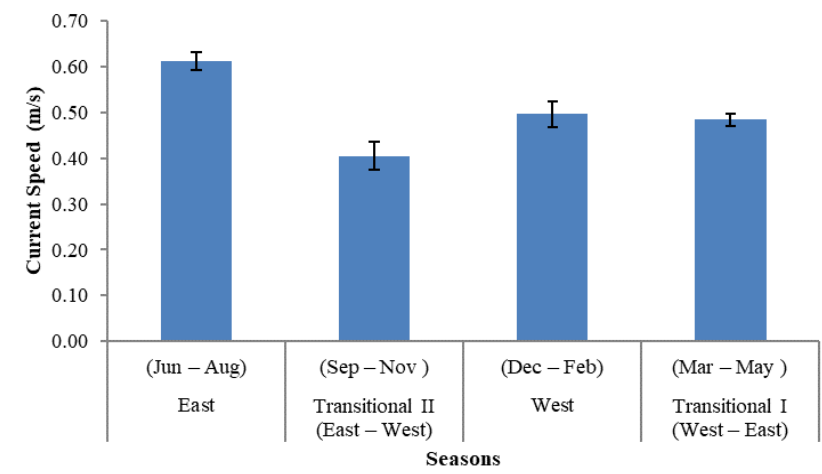

Figure 4. Current distribution in different seasons 


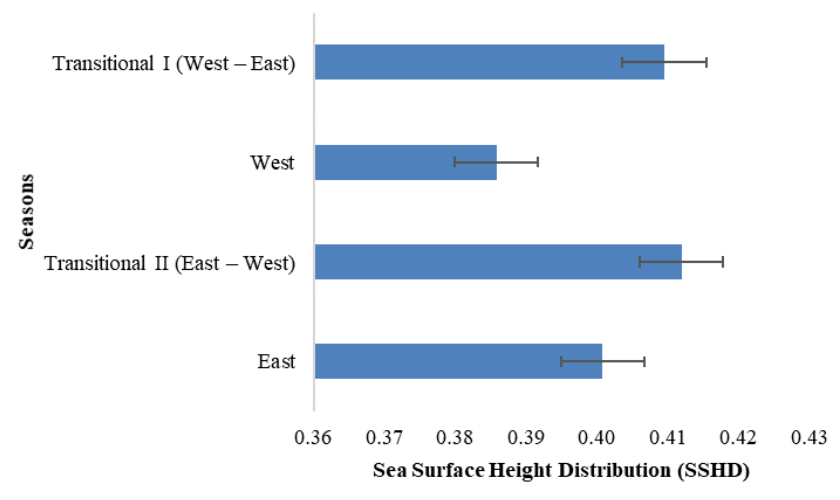

Figure 5. Sea surface height distribution in different seasons

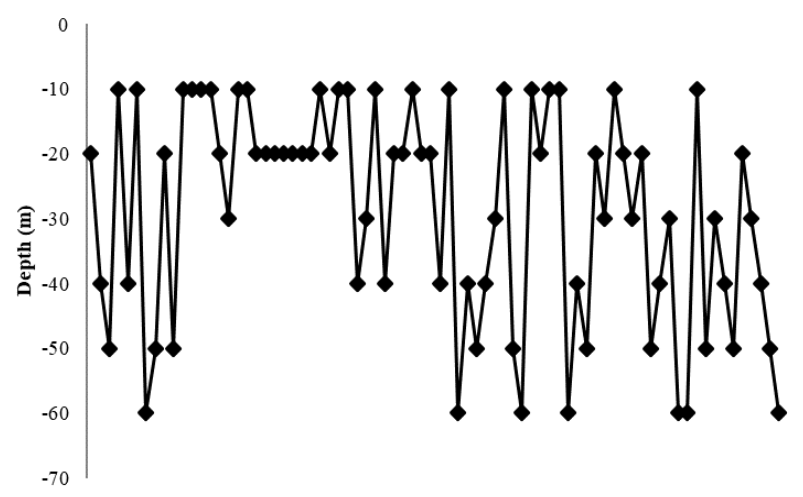

Figure 6. Depth profile (bathymetry) on the research site
The combination of Generalized Additive Model (GAM) equations formed from the five oceanographic variables is shown in Table 2. Equation selection was based on the lowest Akaike Information Criterion (AIC) value and the highest Cumulative Deviance Explained (CDE) value. Based on the results of GAM analysis, the parameters of Sea Surface Temperature (SST) and Chlorophyll- $a$ were the first indicators that significantly affected the presence of whale sharks in the study area. The Akaike Information Criterion (AIC) value of 427.24 and the Cumulative Deviance Explained (CDE) value of 57.30 $\%$. Furthermore, the Bathymetry and SSH parameters were the second indicators with the Akaike Information Criterion (AIC) value of 434.07 and the Cumulative Deviance Explained (CDE) value of $51.40 \%$. In comparison, the Current model was a model that has very little influence on the presence of whale sharks with the Akaike Information Criterion (AIC) value of 436.88 and the Cumulative Value of Deviance Explained (CDE) of $51.40 \%$ (Table 2).

Based on the analysis results, the Generalized Additive Model (GAM) was developed to interpret the effect of each predictor parameter on the presence of whale sharks (Figure 7). Based on the analysis, it can be seen that the negative effect of Sea Surface Temperature (SST) on the presence of whale sharks was at temperatures of $>31.3{ }^{\circ} \mathrm{C}$ and the positive effect was in the temperature range $30.3-$ $31.3{ }^{\circ} \mathrm{C}$. The parameter chlorophyll- $a$ has a positive effect in the range of $0.39-0.86 \mathrm{mg} / \mathrm{L}$ on the presence of whale sharks and a negative effect occurs $<0.39 \mathrm{mg} / \mathrm{L}$ with a high level of confidence. The current parameter has a negative effect of $<0.46 \mathrm{~m} / \mathrm{s}$ and a positive effect was at $0.46 \mathrm{~m} / \mathrm{s}$ and increased to $0.65 \mathrm{~m} / \mathrm{s}$. The positive effect for the depth parameter was at 40 to $50 \mathrm{~m}$, while the positive effect was below 20-40 m. While the SSHD positive effect of 0.63 to $1 \mathrm{~cm}$.

Table 2. Combination results of GAM equations based on P-value, AIC and DE

\begin{tabular}{|c|c|c|c|c|}
\hline Model & Variable & p-Value & AIC & CDE \\
\hline SST & SST & $0.002188 * *$ & 443.48 & $32.50 \%$ \\
\hline $\mathrm{CHL}$ & CHL & $0.002045 * *$ & 446.09 & $29.10 \%$ \\
\hline V_Current & V_Current & $0.0001091 * * *$ & 440.42 & $36.30 \%$ \\
\hline A_Current & A_Current & $5.29905 * * *$ & 439.79 & $37.10 \%$ \\
\hline Bati_m & Bati_m & $0.0009828 * * *$ & 440.50 & $36.20 \%$ \\
\hline SSH & SSH & $1.1605 * * *$ & 436.32 & $41.00 \%$ \\
\hline \multirow[t]{2}{*}{$\mathrm{SST}+\mathrm{CHL}$} & SST & $0.0006744 * * *$ & 427.24 & $57.30 \%$ \\
\hline & $\mathrm{CHL}$ & $0.0003900 * * *$ & & \\
\hline \multirow[t]{2}{*}{ V_Current + A_Current } & V_Current & $0.0009061 * * *$ & 436.88 & $48.80 \%$ \\
\hline & A_Current & $0.0496499 *$ & & \\
\hline \multirow[t]{2}{*}{ Bati_m + SSH } & Bati_m & $0.003908 * *$ & 434.07 & $51.40 \%$ \\
\hline & $\mathrm{SSH}^{-}$ & $0.004042 * *$ & & \\
\hline \multirow[t]{6}{*}{$\mathrm{SST}+\mathrm{CHL}+\mathrm{V} \_$Current + A_Current + Bati_m $+\mathrm{SSH}$} & SST & $0.40708 * * *$ & & \\
\hline & $\mathrm{CHL}$ & $0.66607 * * *$ & & \\
\hline & V_Current & $0.76608 * * *$ & & \\
\hline & A_Current & $0.0002084 * * *$ & 386.39 & $89.20 \%$ \\
\hline & Bati_m & 0.2098652 & & \\
\hline & $\mathrm{SSH}$ & $0.0019857 * *$ & & \\
\hline
\end{tabular}


Sea Surface Height Distribution (SSHD) and depth (Bathymetry) were the second most significant whale shark abundance predictor models. In this study, it can be seen that the maximum Sea Surface Height Distribution (SSHD) was $>0.6 \mathrm{~cm}$, this indicates that sharks are always present when there are small waves and clear water conditions. When there are big waves, whale sharks usually swim at deeper depths (Rowat et al. 2009; Rohner et al. 2013). The results of the depth analysis (bathymetry) showed that whale sharks always appear at a depth of 10-60 m, this depth is an epipelagic zone that whale sharks like (Figure 7). According to Motta et al. (2010), whale sharks are planktonic epipelagic species that spend most of their time at depths of up to $100 \mathrm{~m}$ and often on the surface of the water feeding on plankton. This species is also always present in the mesopelagic zone-and even bathypelagic when in bathymetrically non-limiting habitats (Brunnschweiler et al. 2009; Afonso et al. 2014).

Among the five predictor parameters used in the model, the current is often associated with seasonal occurrence. The average wind ranged between $0.41-0.61 \mathrm{~m} / \mathrm{s}$. It was significant for the abundance of whale sharks, this was indicated by the lowest Akaike Information Criterion (AIC) value and the highest Cumulative Deviance Explained (CDE) (Table 2). In addition, the oceanographic conditions at the study site are diverse and complex. They are influenced by the Indonesian Throughflow, which transports water from the Pacific to the Indian Ocean associated with the ENSO event (Vranes and Gordon 2005). According to Wilson et al. (2001), the Southern Oscillation Index (SOI) effectively measures ENSO (El $\mathrm{Ni}$ no/Southern Oscillation), which is an essential factor influencing the abundance of whale sharks on Ningaloo Reef. Another study, Sleeman et al. (2010) stated that the Southern Oscillation Index (SOI) and wind shear variables positively affect the abundance of whale sharks, thus more sharks are seen when the Southern Oscillation is more robust. Based on the research findings of the (Generalized Additive Model) GAM analysis of the presence of whale sharks in the waters of Cenderwasih Bay National Park, Papua, Indonesia, the oceanographic parameters that have the most influence are Sea Surface Temperature (SST) and Chlorophyll- $a$. At the same time, the bathymetry and Sea Surface Height (SSH) parameters are the second oceanographic parameters that affect the presence of whale sharks. Meanwhile, current parameters have minimal effect on the presence of whale sharks in the waters of Cenderwasih Bay National Park, Papua, Indonesia. This research is expected to contribute and become a reference in managing Satisfied whale sharks in the Cenderawasih Bay National Park area.
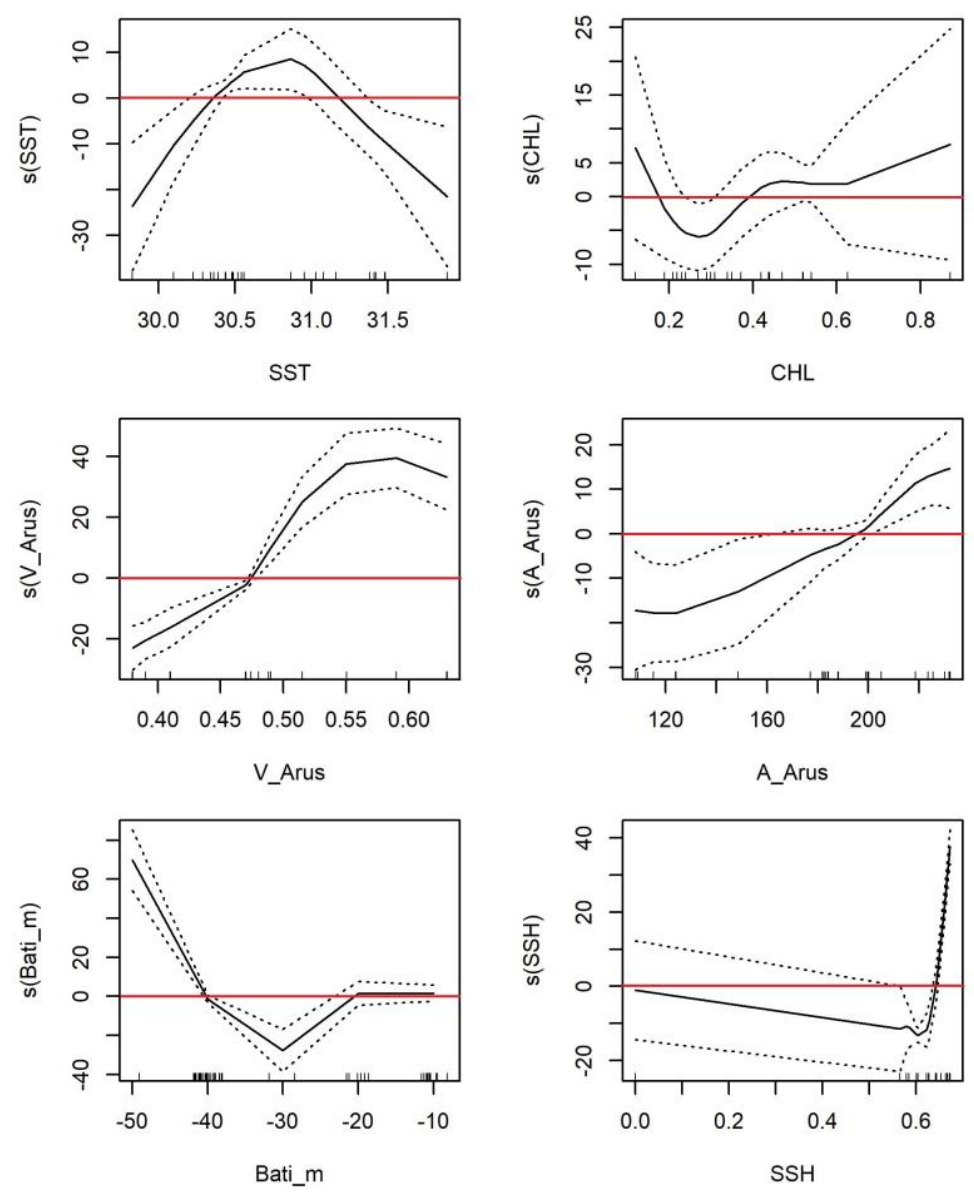

Figure 7. Variable response to the appearance of whale sharks at the study site 


\section{ACKNOWLEDGEMENTS}

All authors would like to thank the Ministry of Education, Culture, Research and Technology of the Republic of Indonesia (KEMENDIKBUD-RISTEK), which provided the Indonesian Lecturer Excellence Scholarship (BUDI) in 2016. The Central Park of Cenderawasih Bay National Park, especially Division III Nabire, has helped the author during the research. A very special thank you to Bram Maruanaya as the manager of Kalilemon Dive Resort, who has provided lodging and speedboats for the author during research activities and to Ahmar Ananto Pratama, who has helped the author in making the map.

\section{REFERENCES}

Afonso P, McGinty N, Machete M. 2014. Dynamics of whale shark occurrence at their fringe oceanic habitat. PLoS ONE 9 (7): e102060. DOI: 10.1371/journal.pone.0102060

Andrzejaczek S, Meeuwig J, Rowat D, Pierce S, Davies T, Fisher R, Meekan M. 2016. The ecological connectivity of whale shark aggregations in the Indian Ocean: A photo-identification approach. $\mathrm{R}$ Soc Open Sci 3: 160455. DOI: 10.1098/rsos.160455

Araujo G, Snow S, So CL, Labaja J, Murray R, Colucci A, Ponzo A. 2017. Population structure, residency patterns and movements of whale sharks in Southern Leyte, Philippines: Results from dedicated photo-ID and citizen science. Aquatic Conserv 27: 237-252. DOI: 10.1002/aqc. 2636

Brunnschweiler JM, Baensch H, Pierce SJ, Sims DW. 2009. Deep-diving behavior of a whale shark Rhincodon typus during long-distance movement in the western Indian Ocean. J Fish Biol 74: 706-714. DOI: $10.1111 / \mathrm{j} .1095-8649.2008 .02155 . x$

Cagua EF, Cochran JEM, Rohner CA, Prebble CEM, Sinclair-Taylor TH, Pierce SJ, Berumen ML. 2015. Acoustic telemetry reveals cryptic residency of whale sharks. Biol Lett 11: 20150092. DOI: 10.1098/rsbl.2015.0092

Cárdenas-Palomo N, Noreña-Barroso E, Herrera-Silveira J, GalvánMagaña F, Hacohen-Domené A. 2018. Feeding habits of the whale shark (Rhincodon typus) inferred by fatty acid profiles in the northern Mexican Caribbean. Environ Biol Fishes 101: 1599-1612.DOI: 10.1007/s10641-018-0806-3

Chassot E, Bonhommeau S, Reygondeau G, Nieto K, Polovina JJ, Huret M, Dulvy NK, Demarcq H. 2011. Satellite remote sensing for an ecosystem approach to fisheries management. ICES J Mar Sci 68: 651-666. DOI: 10.1093/icesjms/fsq195

Clingham E, Brown J, Henry L, Beard A, Dove AD. 2016. Evidence that St. Helena Island is an important multi-use habitat for whale sharks, Rhincodon typus, with the first description of putative mating in this species. PeerJ Prepr 4: e1885v1. DOI: 10.7287/peerj.preprints.1885v1

Comparison of Indonesian Throughflow transport observations, Makassar Strait to eastern Indian Ocean

Copping JP, Stewart BD, McClean CJ, Hancock J, Rees R. 2018. Does bathymetry drive coastal whale shark (Rhincodon typus) aggregations? PeerJ 6: e4904. DOI: 10.7717/peerj.4904

Diamant S, Rohner CA, Kiszka JJ, d'Echon AG, d'Echon TG, Sourisseau E, Pierce SJ. 2018. Movements and habitat use of satellite-tagged whale sharks offwestern Madagascar. Endanger Species Res 36: 4958. DOI: 10.7287/peerj.preprints.3508v1

Donati G, Rees RG, Hancock JW, Jenkins TK, Shameel I, Hindle K, Zareer I, Childs A, Cagua EF. 2016. New insights into the South Ari atoll whale shark, Rhincodon typus, aggregation. QScience Proceedings in the 4th International Whale Shark Conference. Doha, Qatar, 16-18 May 2016. DOI: 10.5339/qproc.2016.iwsc4.16

Duffy CAJ. 2002. Distribution, seasonality, lengths, and feeding behaviour of whale sharks (Rhincodon typus) observed in New Zealand waters. NZJ Mar Freshwater Res 36: 565-570. DOI: 10.1080/00288330.2002.9517112

Eckert SA, Stewart BS. 2001. Telemetry and satellite tracking of whale sharks, Rhincodon typus, in the Sea of Cortez, Mexico, and the North
Pacific Ocean. Environ Biol Fishes 60: 299-308. DOI: 10.1023/A:1007674716437

Elith J, Leathwick JR. 2009. Species distribution models: Ecological explanation and prediction across space and time. Annu Rev Ecol $\begin{array}{llll}\text { Evol } & \text { Syst } & 40: & 677-697 .\end{array}$ 10.1146/annurev.ecolsys.110308.120159

Guisan A, Thuiller W. 2005. Predicting species distribution: Offering more than simple habitat models. Ecol Lett 8: 993-1009. DOI: 10.1111/j.1461-0248.2005.00792.x

Hacohen-Domené A, Martínez-Rincón RO, Galván-Magaña F, CárdenasPalomo N, de la Parra-Venegas R, Galván-Pastoriza B, Dove ADM. 2015. Habitat suitability and environmental factors affecting whale shark (Rhincodon typus) aggregations in the Mexican Caribbean. Environ Biol Fishes 98: 1953-1964. DOI: 10.1007/s10641-015-04135

Hays GC, Ferreira LC, Sequeira AMM, Meekan MG, Duarte CM, Bailey H, Bailleul F, Bowen WD, Caley MJ, Costa DP, Eguíluz VM, Fossette S, Friedlaender AS, Gales N, Gleiss AC, Gunn J, Harcourt R, Hazen EL, Heithaus MR, Thums M. 2016. Key questions in marine megafauna movement ecology. Trends Ecol Evol 31 (6): 463-475. DOI: $10.1016 /$ j.tree.2016.02.015

Ihsan EN, Enita SY, Kunarso, Wirasatriya A. 2018. Oceanographic factors in fishing ground location of anchovy at Teluk Cenderawasih National Park, West Papua: Are these factors have an effect of whale sharks appearance frequencies? IOP Conf Ser Earth Environ Sci 116: 012017.

Klemas V. 2013. Fisheries applications of remote sensing: An overview. Fish Res 148: 124-136. DOI: 10.1016/j.fishres.2012.02.027

McKinney JA, Hoffmayer ER, Wu W, Fulford R, Hendon JM. 2012. Feeding habitat of the whale shark Rhincodon typus in the northern Gulf of Mexico determined using species distribution modelling. Mar Ecol Prog Ser 458: 199-211. DOI: 10.3354/meps09777

Motta PJ, Maslanka M, Hueter RE, Davis RL, de la Parra R, Mulvany SL, Habegger ML, Strother JA, Mara KR, Gardiner JM, Tyminski JP, Zeigler LD. 2010. Feeding anatomy, filter-feeding rate, and diet of whale sharks Rhincodon typus during surface ram filter feeding off the Yucatan Peninsula, Mexico. Zoology 113 (4): 199-212. DOI: 10.1016/j.zool.2009.12.001

Norman B. 2002. CITES Identification Manual Whale Shark (Rhincodon typus Smith 1829). Natural Heritage Trust, Commonwealth of Australia, Camberra. https://www.environment.gov.au/system/files/resources/2ad2cfba5382-4731-8592-02b22893d9b3/files/id-manual.pdf

Norman BM, Whitty JM, Beatty SJ, Reynolds SD, Morgan DL. 2017. Do they stay or do they go? Acoustic monitoring of whale sharks at Ningaloo Marine Park, Western Australia. J Fish Biol 91 (6): 17131720. DOI: $10.1111 /$ jfb.13461

Pajuelo M, Alfaro-Shigueto J, Romero M, Pásara-Polack A, Solano A, Vela G, Sarmiento D, Mangel JC. 2018. Occurrence and bycatch of juvenile and neonate whale sharks (Rhincodon typus) in Peruvian Waters. Pacific Sci 72 (4): 463-473. DOI: 10.2984/72.4.6.

Petatán-Ramírez D, Whitehead DA, Guerrero-Izquierdo T, Ojeda-Ruiz MA, Becerril-García EE. 2020. Habitat suitability of Rhincodon typus in three localities of the Gulf of California: Environmental drivers of seasonal aggregations. J Fish Biol 97 (4): 1177-1186. DOI: $10.1111 /$ jfb. 14496

Pierce SJ, Norman B. 2016. Whale shark Rhincodon typus. Flora 8235: 128.

Robinson DP, Jaidah MY, Bach SS, Rohner CA, Jabado RW, Ormond R, Pierce SJ. 2017. Some like it hot: Repeat migration and residency of whale sharks within an extreme natural environment. PloS ONE 12 (9): e0185360. DOI: 10.1371/journal.pone.0185360

Rohner CA, Flam AL, Pierce SJ, Marshall AD. 2017. Steep declines in sightings of manta rays and devilrays (Mobulidae) in Southern Mozambique. PeerJ Prepr. 5: e3051v1. DOI: 10.7287/peerj.preprints.3051v1

Rohner CA, Pierce SJ, Marshall AD, Weeks SJ, Bennett MB, Richardson AJ. 2013. Trends in sightings and environmental influences on a coastal aggregation of manta rays and whale sharks. Mar Ecol Prog Ser 482: 153-168. DOI: 10.3354/meps10290.

Rohner CA, Richardson AJ, Jaine FRA, Bennett MB, Weeks SJ, Cliff G, Robinson DP, Reeve-arnold KE, Pierce SJ. 2018. Satellite tagging highlights the importance of productive Mozambican coastal waters to the ecology and conservation of whale sharks. PeerJ 6: e4161. DOI: $10.7717 /$ peerj.4161 
Rowat D, Engelhardt U. 2007. Seychelles: A case study of community involvement in the development of whale shark ecotourism and its socio-economic impact. Fish Res 84 (1): 109-113. DOI: 10.1016/j.fishres.2006.11.018

Rowat D, Speed CW, Meekan MG, Gore MA, Bradshaw CJA. 2009. Population abundance and apparent survival of the vulnerable whale shark Rhincodon typus in the Seychelles aggregation. Oryx 43 (4): 591-598. DOI: 10.1017/S0030605309990408

Ryan JP, Green JR, Espinoza E, Hearn AR. 2017. Association of whale sharks (Rhincodon typus) with thermo-biological frontal systems of the Eastern Tropical Pacific. PLoS ONE 12: e0182599. DOI: 10.1371/journal.pone.0182599

Sequeira AMM, Mellin C, Fordham DA, Meekan MG, Bradshaw CJA. 2014. Predicting current and future global distributions of whale sharks. Glob Chang Biol 20: 778-789. DOI: 10.1111/gcb.12343

Sequeira AMM, Mellin C, Rowat D, Meekan MG, Bradshaw CJA. 2012 Ocean scale prediction of whale shark distribution. Divers Distrib 18 (5): 504-518. DOI: 10.1111/j.1472-4642.2011.00853.X

Siswanto E, Horii T, Iskandar I, Gaol JL, Setiawan RY, Susanto RD. 2020. Impacts of climate changes on the phytoplankton biomass of the Indonesian Maritime Continent. J Mar Syst 212: 103451. DOI: 10.1016/j.jmarsys.2020.103451

Sleeman JC, Meekan MG, Fitzpatrick BJ, Steinberg CR, Ancel R, Bradshaw CJA. 2010. Oceanographic and atmospheric phenomena influence the abundance of whale sharks at Ningaloo Reef, Western Australia. J Exp Mar Biol Ecol 382 (2): 77-81. DOI: 10.1016/j.jembe.2009.10.015

Sleeman JC, Meekan MG, Wilson SG, Jenner CKS, Jenner MN, Boggs GS, Steinberg CC, Bradshaw CJA. 2007. Biophysical correlates of relative abundances of marine megafauna at Ningaloo Reef, Western Australia. Mar Freshw Res 58 (7): 608-623.

Stewart BS. 2012. Whale Shark Research Expedition to Teluk Cenderawasih National Park, West Papua \& Papua, Indonesia 9 - 18 June 2012. World Wildlife Fund Indonesia \& Conservation International. Hubbs-SeaWorld Research Institute 2595 Ingraham Street San Diego, CA 92109. 15 July 2012 HSWRI Technical Report 2012-379.

Taylor JG. 1996. Seasonal occurrence, distribution and movements of the whale shark, Rhincodon typus, at Ningaloo Reef, Western Australia. Mar Freshw Res 47 (4): 637-642. DOI: 10.1071/MF9960637

Vranes K, Gordon AL. 2005. Geophys Res Lett 32: L10606, DOI: 10.1029/2004GL022158

Wilson SG, Taylor JG, Pearce AF. 2001. The seasonal aggregation of whale sharks at Ningaloo Reef, Western Australia: Currents, migrations and the El Niño/Southern Oscillation. Environ Biol Fishes 61: 1-11. DOI: 10.1023/A:1011069914753

Wood SN. 2006. Low rank scale invariant tensor product smooths for Generalized Additive Mixed Models. Biometrics 62 (4):1025-1036 